\title{
Resection of proximal left main bronchus carcinoma
}

\author{
R ABBEY SMITH AND B K NIGAM
}

From the Cardiothoracic Unit, Walsgrave Hospital, Coventry, UK

ABSTRACT A carcinoma at the orifice of the left main bronchus is generally considered inoperable. Since 1963, in six patients, we have mobilised the transverse aortic arch and, working above the aortic arch, cut the left main bronchus off the trachea and closed the stump. The operation is completed as a pneumonectomy; it is referred to as a supra-aortic pneumonectomy. The indications, technique, and results are described.

Opinions differ concerning the operability of carcinoma in the proximal $2 \mathrm{~cm}$ of the left main bronchus (fig 1). Some surgeons consider such a malignant tumour to be inoperable. It is difficult to estimate the proportion of surgeons who hold this belief, because so little has been written about the difference in prognosis between carcinoma of the origin of the right and that of the left main bronchus. For instance, Lee (1972), in a comprehensive review of factors affecting operability and resectability of lung carcinoma, does not specify a difference, perhaps because it is too obvious to need emphasising.

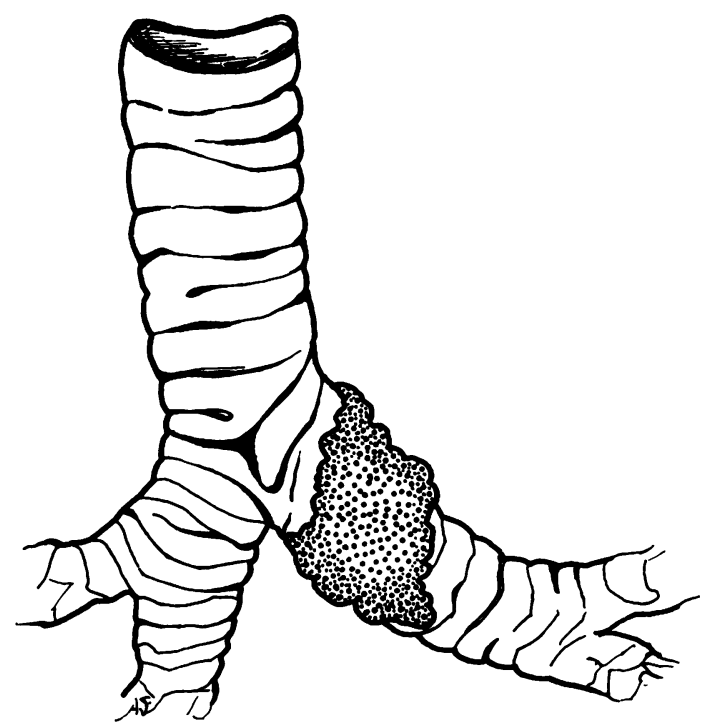

Fig 1 Sketch of trachea, carina, and both main bronchi, viewed from in front. Stippled portion of left main bronchus is area of doubtful operability.
In some cases of left pneumonectomy by conventional means, main bronchus division will be $\frac{0}{0}$ across malignant tissue and healing may be un- $\frac{\mathbb{Q}}{-}$ satisfactory. Stump recurrence can occur, although $\vec{\varphi}$

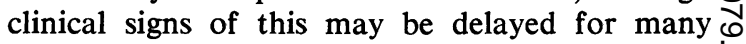
years. Also, the bronchoscopic indications of inoperability of left main bronchus carcinomas are not well defined. Fixity or proximity of the tumour to the carina, the exact site of origin within the bronchus, and the degree of invasion of the im- $\frac{\alpha}{\Phi}$ mediate peribronchial tissues, are matters of $\stackrel{\varrho}{\Rightarrow}$ opinion rather than of fact. Experience will enable음 the surgeon to decide whether in a particular case $\frac{3}{\sqrt{3}}$ all macroscopic carcinoma can be resected by the conventional approach to the bronchus as it emerges below the aortic arch.

A number of our early attempts at conventional left pneumonectomy for carcinoma of the proxi- $-\dot{x}$ mal left main bronchus were not successful often 3 . enough for us to continue to use the conventional approach. Maxwell Chamberlain (1964) recommended passing a tape around the trachea and, $\mathrm{O}$ by pulling on this tape in the line of the bronchus, he could expose the full length of the left maino bronchus and cut it off the lateral wall of the trachea. We have never been able to obtain aos clear view of the tracheal wall and the carinaN working below the aortic arch and, should such a N view be obtained, we should have little confidence ${ }_{-}$ in the soundness of the stump closure because the aortic arch obstructs the view. The stump is at the bottom of a narrow, deep hole. The posterior wallo of the tracheobronchial tree is so friable and easily torn that exposure must be adequate for a properō closure of the stump to be effected. Exposure of this area in the cadaver confirmed that an excel- $\frac{\vec{D}}{\mathrm{D}}$ lent exposure of the carina and the lower $2 \mathrm{~cm} \frac{\varrho}{\sigma}$ of the left lateral tracheal wall can be obtained by 
mobilisation and downward retraction of the aortic arch.

\section{Indications for supra-aortic pneumonectomy}

The indication for considering the use of this method is a tumour (malignant or benign) in the left main bronchus which an experienced surgeon decides cannot be resected by conventional left pneumonectomy. The method has been used in six patients during the past 15 years; it is therefore rarely needed but is invaluable when the correct indications for its use exist.

\section{The Operation}

A Robertshaw double lumen endobronchial tube must be placed in the right main bronchus. The patient is placed in the prone (Overholt) position on the operating table. The fifth left rib is widely resected, the pleural cavity entered, and full exposure obtained by using a Finochietto rib spreader. Resectability is confirmed. The oesophagus is usually adherent to the inner margin of the left main bronchus and the carcinoma may also be adherent to the adventitial wall of the aorta in the concavity of the arch. An intrapericardial approach has been necessary for access to the major hilar vessels and satisfactory control of the left pulmonary artery and the left superior pulmonary vein (table). The mediastinal pleura is incised along the convexity of the aortic arch for $6 \mathrm{~cm}$, centred on the origin of the left subclavian artery. The superior intercostal vein is ligated and divided as are the first three aortic branches distal to the left subclavian. The ligamentum arteriosum and the vagus nerve as it lies on the posterior wall of the left main bronchus are divided; the vagus is picked up and dissected to show the left recurrent laryngeal nerve, which is carefully preserved. The pleura is freed from the arch to the point where it is reflected off the bronchus. The tumour may be indented by the aortic arch, but we have never seen actual invasion of the wall of the aorta. The first finger is passed around the arch to its medial surface and the carina palpated; the carina and the right main bronchus can easily be seen by retraction of the arch, using a Cumming's aortic retractor (fig 2). The oesophagus, especially if it has been pulled to the left side because of its fixity to the carcinoma, may impede full exposure: this can readily be corrected by pledget retraction of the oesophagus.

As the first step in the lung removal, a decision is made whether to cut the bronchus off at the tracheobronchial angle or to secure the hilar vessels. We prefer to cut the bronchus and close the stump before completing the pneumonectomy. Before starting the amputation of the bronchus it is wise to confirm, by making a small initial cut in the trachea, that no leak is present suggesting malfunction or malposition of the Robertshaw

Details of six supra-aortic pneumonectomy operations

\begin{tabular}{|c|c|c|c|c|c|c|c|c|c|}
\hline Patient & $\begin{array}{l}\text { Age at } \\
\text { operation }\end{array}$ & $\begin{array}{l}\text { Date of } \\
\text { operation }\end{array}$ & $\begin{array}{l}\text { Histological } \\
\text { type }\end{array}$ & $\begin{array}{l}\text { Site of } \\
\text { affected } \\
\text { nodes }\end{array}$ & $\begin{array}{l}\text { Other structures } \\
\text { affected }\end{array}$ & $\begin{array}{l}\text { Method of securing } \\
\text { hilar vessels }\end{array}$ & $\begin{array}{l}\text { Other } \\
\text { treatment }\end{array}$ & $\begin{array}{l}\text { Period of } \\
\text { survival } \\
(y r)\end{array}$ & Result \\
\hline 1 & 41 & 1963 & $\begin{array}{l}\text { Squamous } \\
\text { cell }\end{array}$ & None & Left atrial wall & $\begin{array}{l}\text { Ligature PA. Clamp } \\
\text { and suture atrial wall }\end{array}$ & None & 11 & $\begin{array}{l}\text { Died 1974. Cerebro- } \\
\text { vascular accident: } \\
\text { confirmed by necropsy }\end{array}$ \\
\hline 2 & 51 & 1963 & $\begin{array}{l}\text { Squamous } \\
\text { cell }\end{array}$ & Hilar & Left atrial wall & $\begin{array}{l}\text { Ligature PA. Clamp } \\
\text { and suture atrial } \\
\text { wall }\end{array}$ & None & 14 & $\begin{array}{l}\text { Died } 1977 . \text { Second } \\
\text { primary carcinoma } \\
\text { lung (see fig } 4 \text { ): } \\
\text { confirmed by } \\
\text { necropsy }\end{array}$ \\
\hline 3 & 55 & 1968 & $\begin{array}{l}\text { Anaplastic } \\
\text { large cell }\end{array}$ & $\begin{array}{l}\text { Medias- } \\
\text { tinal }\end{array}$ & $\begin{array}{l}\text { Superficial } \\
\text { muscle fibres } \\
\text { of oesophagus }\end{array}$ & $\begin{array}{l}\text { Clamp and suture } \\
\text { PA. Clamp and } \\
\text { suture both PVs }\end{array}$ & None & 2 & $\begin{array}{l}\text { Died 1971. Local } \\
\text { extension of } \\
\text { carcinoma }\end{array}$ \\
\hline 4 & 56 & 1976 & $\begin{array}{l}\text { Squamous } \\
\text { cell }\end{array}$ & Hilar & None & $\begin{array}{l}\text { Clamp and suture } \\
\text { PA. Ligature both } \\
\text { PVs }\end{array}$ & None & 3 & Alive and well \\
\hline 5 & 54 & 1976 & $\begin{array}{l}\text { Squamous } \\
\text { cell }\end{array}$ & Hilar & None & $\begin{array}{l}\text { Clamp and suture } \\
\text { PA. Clamp and } \\
\text { suture superior PV. } \\
\text { Ligature inferior PV }\end{array}$ & $\begin{array}{l}\text { Radio- } \\
\text { therapy }\end{array}$ & 2 & $\begin{array}{l}\text { Died 1978. Local } \\
\text { extension of carcinoma }\end{array}$ \\
\hline 6 & 54 & 1978 & $\begin{array}{l}\text { Squamous } \\
\text { cell }\end{array}$ & Hilar & $\begin{array}{l}\text { Adventitia of } \\
\text { concavity of } \\
\text { aortic arch }\end{array}$ & $\begin{array}{l}\text { Clamp and suture } \\
\text { PA. Clamp and } \\
\text { suture both PVs }\end{array}$ & None & 1 & Alive and well \\
\hline
\end{tabular}

Each operation an intrapericardial pneumonectomy. Average age at operation 51.8 years.

PA = Pulmonary artery; PV= Pulmonary vein. 


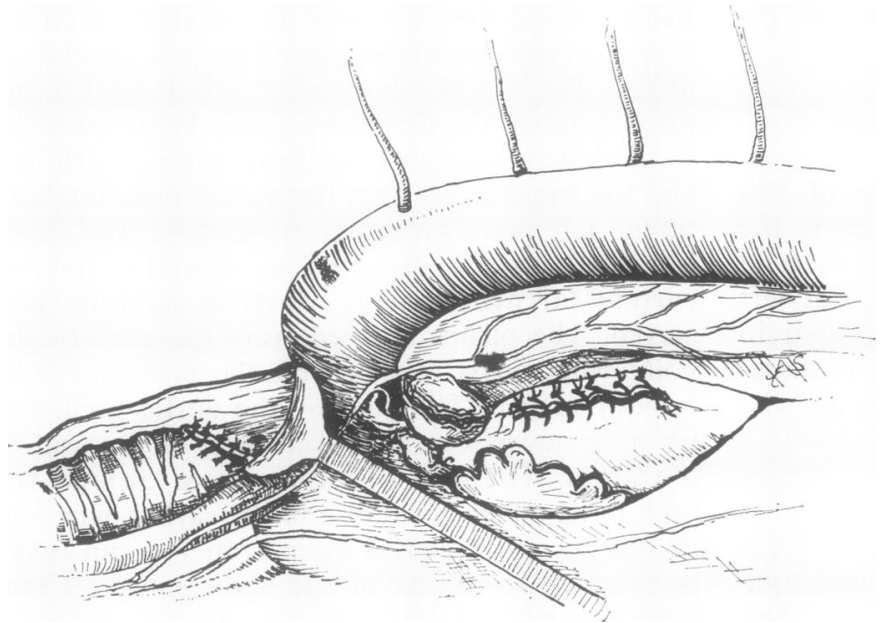

Fig 2 Sketch of operative procedure; patient in prone position. An intrapericardial pneumonectomy has been performed. Left subclavian artery is being $\vec{\omega}$ retracted to show suture line in trachea. Intact recurrent laryngeal nerve can be seen looping around ligamentum arteriosum.

tube in the right main bronchus. When maintenance of the anaesthetic gas pressure is indisputably confirmed, the initial cut is extended from the lower lateral wall of the trachea to a point close to the carina. If the carina itself is incised narrowing of the right main bronchus may occur when the tracheobronchial stump is closed. Interrupted linen thread sutures mounted on atraumatic needles are used. The left main bronchus containing the carcinoma is pulled out below the aortic arch. A portion of bronchus at the line of transection may be sent for frozen section and histological examination. The pneumonectomy is then com- pleted intrapericardially. It has been found necessary to clamp and suture either the pulmonarye artery or the vein, or both, because of carcinoma. affecting the extrapericardial portion of these vessels and doubts about the safety of simples ligation.

The oesophagus must be retracted and protected at all stages of the operation. It is the organ most $\stackrel{\square}{\square}$ at risk of inadvertent damage. The thoracic duct, $\vec{\overrightarrow{ }}$ never identified in any of the six cases, lies behind 3 and slightly to the left of the oesophagus at aortic arch level; the recurrent laryngeal nerve can beo seen in the space between the oesophagus and the

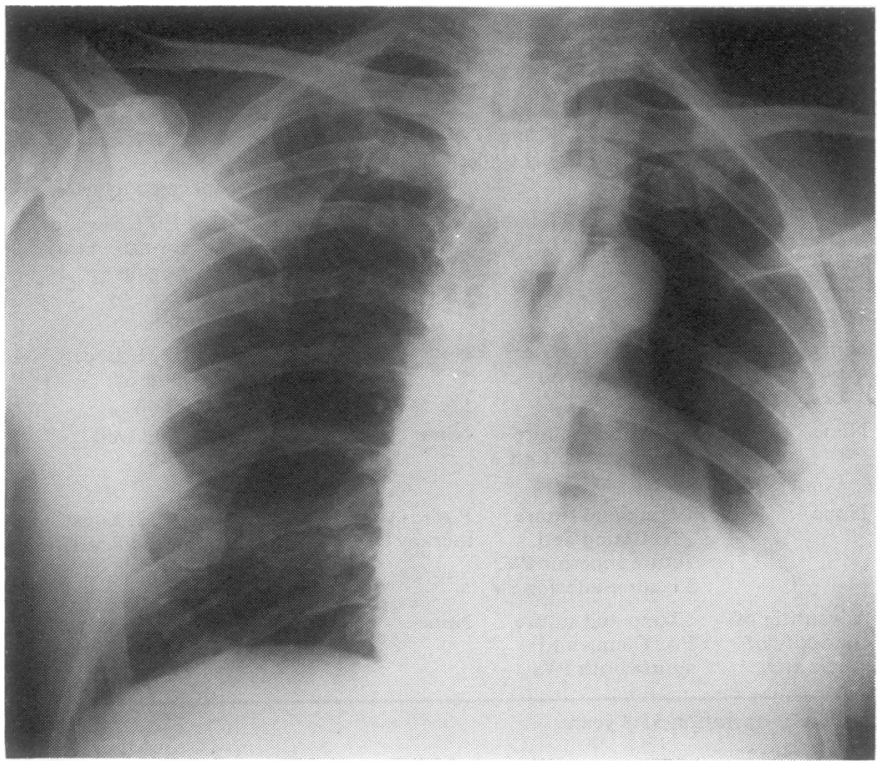

Fig 3 Portable radiograph of chest taken N 30 minutes after completion of supraaortic pneumonectomy. Unusual position of aortic arch is a characteristic appearance. Arch returns to its normal position within first two weeks after operation. 
trachea. The opening in the pericardium, if larger than $2.5 \mathrm{~cm}$ in its greatest width, is closed with Dacron strips. The chest wall is closed without drainage of the space and the pressure adjusted to a mean negative pressure.

A routine chest radiograph is taken immediately after operation with the patient sitting up; fig 3 illustrates the typical appearances. Fluids by mouth are withheld for the first 24 hours or until operative damage to the oesophagus is excluded. Aspiration of the pneumonectomy space should be undertaken within the first 24 hours and the aspirate examined for evidence of contamination of the space by oesophageal contents. We prefer this method of management to the insertion of a tube into the space at the time of pneumonectomy.

Five of the six patients left hospital without complications before the 14 th day after operation. Patient 4 (table) developed a chylous leak into the pneumonectomy space and a total of $3200 \mathrm{ml}$ of bloodstained chyle was aspirated during the first two weeks. No other treatment was required, and the patient returned home three weeks after operation. This trivial complication is the only one observed.

No voice changes from left recurrent laryngeal nerve damage, and no interference with stump healing from division of the two left bronchial arteries (which are branches of the descending aorta arising immediately distal to the left subclavian) were noted.

The site and number of aortic branches that can be divided without causing spinal cord damage vary and damage may depend on several factors.

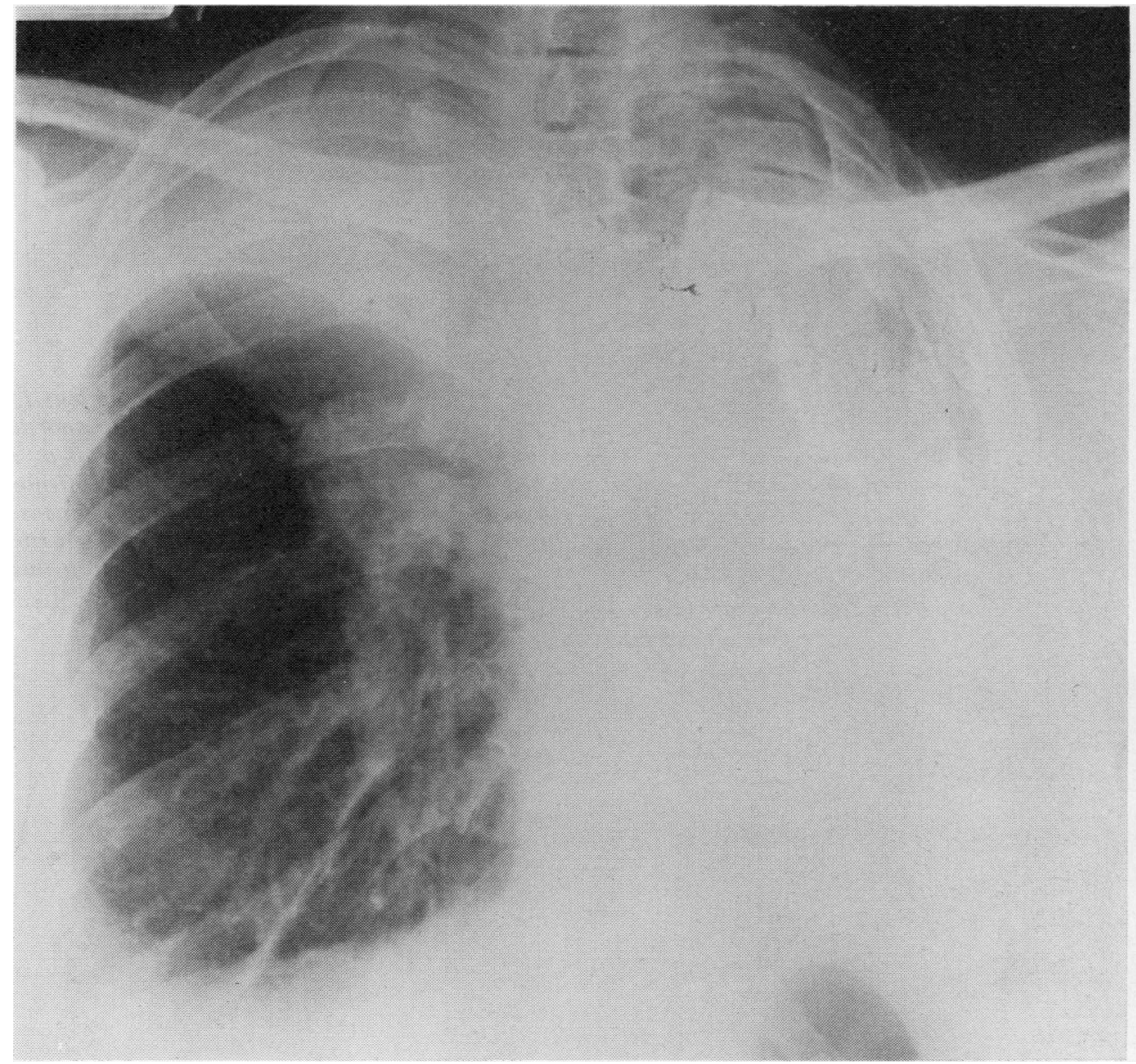

Fig 4 Chest radiograph of patient 2 (table) taken 14 years after supra-aortic pneumonectomy, showing second primary lung carcinoma in right upper lobe. Pleura of pneumonectomy space is calcified. 
There were no sequelae from compression of the left subclavian artery by the aortic retractor.

\section{Results}

The results are summarised in the table and figs 4 and 5: they justify the continued use of the method for the young patient whose cardiorespiratory function is sufficient to tolerate pneumonectomy and when, because of the particular position of the carcinoma in the left main bronchus, the alternative is to regard the lesion as unresectable.

\section{References}

Chamberlain, J M (1964). Personal communication. Lee, Y-T N (1972). Prognostic factors in surgical treatment of bronchogenic carcinoma. Surgery, Gynecology and Obstetrics, 135, 961-975.

Requests for reprints to: $\mathbf{R}$ Abbey Smith, Cardiothoracic Unit, Walsgrave Hospital, Coventry CV2 2DX.

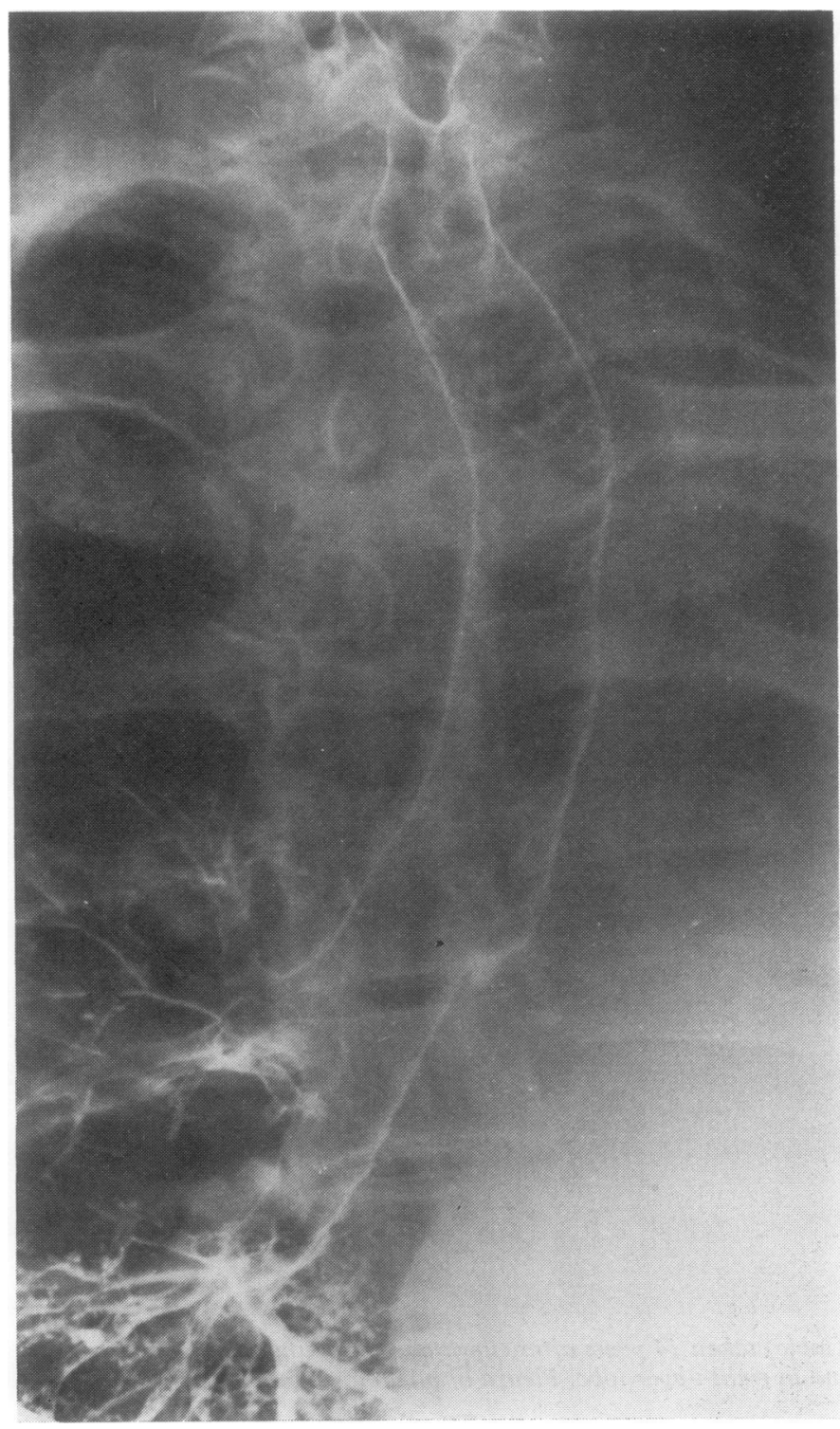

Fig 5 Tracheogram of patient 1 (table) taken five years after supra-aortic pneumonectomy. Absence of a "stump" of left main bronchus is illustrated; resection of left main bronchus is as radical as is possible. Sixth left rib in error for fifth was resected in this patient. 